\title{
EXPERIMENTAL ULCERATIVE COLITIS: TGF-B AS A DIAGNOSTIC MARKER
}

\author{
Omar A.M. Farghaly ${ }^{1 *}$, Hosny A. Hasan ${ }^{2,}$ Hesham H.Taha ${ }^{1}$, Abeer Sharaf-Eldin ${ }^{3}$, Kawkab \\ A. Ahmed ${ }^{4}$ Omar M.M. Mohafez ${ }^{1}$ \\ ${ }^{1}$ Department of Biochemestry, Faculty of Pharmacy, Al-Azhar University, Assiut, \\ Egypt. \\ ${ }^{2}$ Department of Biochemestry, Faculty of Medicin, Assiut University, Assiut, Egypt. \\ ${ }^{3}$ Department of Gastroenterology and Tropical Medicin, Faculty of Medicin, Assiut \\ University, Assiut, Egypt. \\ ${ }^{4}$ Department of Pathology, Faculty of Veterinary Medicine, Cairo University, Giza, \\ Egypt.
}

*Correspondent auther: omarfarghaly@azhar.edu.eg

\begin{abstract}
Background:

Previous studies stated that TGF- $\beta$ is a pleiotropic cytokine, abundant in mammalian intestine, regulates multiple cellular functions as a suppressor of the immune response, cell proliferation, and oncogenesis. Study aims: Here, we investigated the value of TGF- $\beta$ as a diagnostic marker of ulcerative colitis disease (UC) in experimental UC model. Materials \& Methods: Acute \& chronic UC was induced in mice by using (3\% and $1.5 \%$ respectively) DSS in drinking water. The induction of UC was confirmed by histopathological examination. Proteins and mRNA expression of both TGF- $\beta$ and TNF- $\alpha$ were analyzed by western blot and real time PCR respectively. Complete blood count (CBC), C-reactive protein (CRP), erythrocyte sedimentation rate (ESR). Results: A marked elevation occurred in proteins and mRNA expression of both TGF- $\beta$ and TNF- $\alpha$ in UC tissues in acute and chronic groups vs. healthy group. Furthermore, significant elevation in both CRP and ESR of diseased groups was recorded in comparison to normal group. Blood count revealed marked leukocytosis, thrombocytosis and marked decrease in red blood cell counts with severe anemia in both acute and chronic UC groups compared to healthy control group. Conclusion: Increased levels of TGF- $\beta$ protein and mRNA expression in UC disease might have a diagnostic value side by side with inflammatory biomarkers (TNF- $\alpha$, CRP \& ESR), leukocytosis, thrombocytosis, bloody diarrhea and histopathological changes.
\end{abstract}

Keywords: Acute \& Chronic Ulcerative Colitis (UC), Transforming growth factor beta (TGF- $\beta$ ), C - reactive protein (CRP), Erythrocyte sedimentation rate (ESR), Tumor necrosis factor alpha $(\mathrm{TNF}-\alpha)$. 


\section{Introduction}

Ulcerative colitis (UC) is a type of inflammatory bowel diseases (IBD) characterized by inflammation typically bounded to colon with continuous lesions and damage the mucosal layer only (Satsangi et al., 2006, Gray et al., 2010). IBD including UC has become a worldwide disease; burden remains high as prevalence overpass $0.3 \%$ in newly industrialized countries (Ng et al., 2017).

In Egypt, Esmat et al. reported that, over 15 year period from 1995 to 2009, the Gastroenterology Center in Faculty of Medicine, Cairo University, received 24156 patients, a total of 157 patients were diagnosed IBD with prevalence $0.6 \%$. Of these, 135 patients were diagnosed with UC ( $86 \%$ of the total), and 22 patients with Crohn's disease CD (14\% of the total) (Esmat et al., 2014).

Ulcerative colitis is associated with complications within the digestive system as abdominal pain, bloody diarrhea and toxic megacolon, and outside the digestive system which may include; hepatobiliary system, genitourinary, musculoskeletal, pulmonary, cardiac, ocular, and dermatologic disorders (Chan et al., 2015, Manser et al., 2016).

The most well known risk factors for IBD are; smoking, appendectomy, low fiber diet intake, vitamin D deficiency, ethnicity, depression, anxiety and stress (Ananthakrishnan 2015), infections with Helicobacter pylori, Campylobacter, and Salmonella (Wu et al., 2015). Also, some medications as non-steroidal antiinflammatory drugs, oral contraceptives and antibiotics have an association with IBD (Ye et al., 2015).

Diagnosis of IBD usually depends on the combination of; clinical symptoms, laboratory findings, radiology, endoscopy, and biopsy histology (Fengming and Jianbing 2014). Some markers related to inflammation or disease activity as; Creactive protein, erythrocyte sedimentation rate, platelets count, red blood cell distribution, and fecal Calprotectin (Burri et al., 2014). However, these biomarkers show low sensitivity in mild to moderate UC patients, consequently, they can only be used as an adjunct to endoscopy and radiology procedure (Norouzinia et al., 2017).

\section{Role of transforming growth factor beta (TGF $\beta$ ) in UC}

In mammalian intestine TGF- $\beta$ is produced by many cell types; epithelial cells, immune cells (Dendritic \& Treg), and fibroblasts. The production of TGF- $\beta$ is upregulated by many factors such as bacteria, virus, cytokines, apoptotic cells, and the autocrine/paracrine loop (Kashiwagi et al., 2015). TGF- $\beta$ is secreted in an inactive or latent form, then, latent TGF- $\beta$ is activated by serine proteases or metalloproteinases. In this processes, integrines function as critical co-factor of TGF- $\beta$ activation (Jenkins 2008). Activated TGF- $\beta$ binds to the TGF- $\beta$ receptors on immune cells (T-cells, B-cells, dantritic cells, and macrophages) and epithelial cells, which activate the intracellular transduction through Smad pathways and contribute to intestinal homeostasis (Ihara et al., 2017). 
In the Smad-dependent pathway, phosphorylated Smad2 and Smad3 form a complex with Smad4 and enter the nucleus to regulate the transcription of target genes (Johnston et al., 2016). Smad7 is a downstream target of the TGF- $\beta$ pathway that binds to TGF- $\beta$ receptor type | (TGF $\beta$ R $\mid)$ and acts in a negative-feedback mannar to inhibit TGF- $\beta$ pathway (Monteleone et al., 2001).

The most vastly used mouse models of UC use dextran sodium Sulphate (DSS) to induce epithelial damage. The DSS model facilitate IBD research due to its, simplicity, rapidity \& reproducibility. Acute, chronic and relapsing models of UC can be carried out by using DSS.

\section{Materials and Methods}

\subsection{Reagents:}

Mouse monoclonal anti-TGF- $\beta$ (cat\# sc-130348), mouse monoclonal anti- $\beta$ actin (cat\# sc-81178), and TNF- $\alpha$ (cat\# sc-52746) primary antibodies were obtained from Santa Cruz Co. Alkaline phosphatase labeled secondary anti-mouse antibody was obtained from Novus Co. (cat\# NB 7524, Littleton, USA). Total RNA extraction kit was provided by Qiagen CO. (cat. No. /ID: 74104). Reverse Transcriptase enzyme was obtained from Applied Biosystems CO. (cat.No.4368813). SYBR Green master mix was provided by Qiagen CO. (cat.No.K0251). CRP was measured by CRP-Latex kit provided by Biosystems Co. (cat. No. 2291). Dextran sodium sulfate salt (DSS), MW 40,000 powder obtained from Alfa Aesar Co. (cat\# J63606). All other chemicals and solvents used in this study were of analytical grade and were obtained from Sigma Chemical Co. or other commercial suppliers.

\subsection{Experimental UC Model:}

Fifteen BALB/c mice $6-8$ weeks old and $15 \pm 2 \mathrm{~g}$ weight were used. Mice were obtained and maintained in the animal house of Faculty of Medicine, Assiut University under standard laboratory conditions $\left(12 / 12 \mathrm{hrs}\right.$ light $/$ dark cycle, $21 \pm 2{ }^{\circ} \mathrm{C}$ with relative humidity of $55 \%$ ) and were allowed free access to standard mice pellets and tap water. All animals received professional human care in compliance with International Ethical Guidelines for Animal Care (US Naval Medical Research Center, Unit No.3, Abbaseya, Cairo, Egypt) accredited by the Association for Assessment and Accreditation of Laboratory Animal Care International. Animals were randomly divided into three groups of fife mice each. Acute UC was induced by fed the mice with $3 \%(\mathrm{w} / \mathrm{v})$ DSS in their drinking ( $3 \mathrm{~g}$ DSS dissolved in $100 \mathrm{ml}$ distilled water) water for 7 days, while chronic colitis was induced in mice after administration of $1.5 \%$ DSS for 14 days $(1.5 \mathrm{~g}$ DSS dissolved in $100 \mathrm{ml}$ distilled water) (Perše and Cerar 2012). Healthy control mice received normal water. The progression of colitis was monitored in a blinded manner, including measurement of body weight, evaluation of stool consistency, and presence of rectal bleeding tested by guaiac paper. Disease activity index (DAI) was represented as the sum of scores for weight loss, stool consistency and rectal bleeding. 


\subsection{Sample Collection:}

At the end of the experiment, the animals were anaesthetized with light diethyl ether. Blood was collected via right heart ventricle puncture. Blood samples were collected into three tubes; EDTA tube for complete blood count, Westergren tube for estimation of erythrocyte sedimentation rate (ESR), and plain tube for separation of serum to measure $\mathrm{C}$-reactive protein. The colons were isolated immediately after sacrificing, washed with ice cold isotonic saline, blot dried and divided into pieces, and flash-frozen in liquid nitrogen and stored at $-80{ }^{\circ} \mathrm{C}$. Another part from colon of all animals were collected in RNAlater and stored at $-20{ }^{\circ} \mathrm{C}$ for total RNA extraction. Other specimens from colon of all animals were collected, fixed in neutral buffered formalin $10 \%$ for histopathological examination.

\subsection{Histopathological Examination:}

Specimens from colon of all animals were collected, fixed in neutral buffered formalin $10 \%$ and processed by paraffin embedding technique. Transverse sections of 4$5 \mu \mathrm{m}$ thick were prepared and stained with Haematoxylin and Eosin for light microscopic examination. A semi-quantitative histological assessment of colon lesions was carried out, three sections of hematoxylin/ eosin-stained colon were examined using a light microscope (Olympus BX45), and scored with a slightly modified method. The alterations were graded as (0) indicated no changes, (1), (2) and (3) indicated mild, moderate and severe changes, respectively, while the grading severity was determined by percentage as follows: (5- 10\%) showed mild changes, $(<10 \%-20 \%)$ indicated moderate changes and changes more than $(>20 \%)$ indicated severe changes.

\subsection{Western Blot Analysis:}

Colon tissue was homogenized in $1.5 \mathrm{ml}$ ice-cold lysis buffer containing protease inhibitors by Glass-Col Homogenizer, centrifuges at to $600 \times \mathrm{g}$ for $15 \mathrm{~min}$ sediment debris. Protein concentrations were determined by BCA protein assay kit. 50 $\mu \mathrm{g}$ protein amount of homogenate supernatant were denatured by boiling in $2 \%$ sodium dodecyl sulfate (SDS) and 5\% 2-mercaptoethanol for 5 minutes and loaded in each lane. $12 \%$ SDS-polyacrylamide gel (SDS-PAGE) was electrophoresed at 100 volts for 120 minutes. The protein was semidry transferred onto nitrocellulose membrane (T-77 ECL, Amersham Biosciences) for 120 minutes. Then membrane was blocked by $5 \%$ defatted milk dissolved in Tris buffered saline with tween (TBST buffer) for 60 minutes and was incubated with primary antibody (at dilution 1: 1500) overnight. Then was incubated with 1: 5000 diluted alkaline phosphatase labeled secondary anti-mouse antibody in $10 \%$ diluted blocking buffer. The bands of the proteins were detected by using 5bromo-4-chloro-3-indoryl phosphate/nitroblue tetrazolium detection system and Tris$\mathrm{Hcl}$ buffer / magnesium chloride. These incubations procedures included primary and secondary antibodies against; TGF- $\beta$, TNF- $\alpha$, and $\beta$-actin.

\subsection{RNA Isolation and qRT-PCR:}

Total RNA was extracted from colon tissues using RNeasy Mini kit reagent (Qiagen, Germany) per manufacture instructions. RNA concentrations were determined 
spectrophotometrically by Nanodrop (Thermo Fisher Scientifics, Waltham, MA). Synthesis of double-stranded cDNA was achieved by using High Capacity cDNA Reverse Transcription kit (Applied Biosystems, USA) according to manufacture instructions. Produced cDNA was subjected to qPCR using a StepOnePlus ${ }^{\mathrm{TM}}$ Real-Time PCR system (Applied Biosystems, USA) with Maxima SYBR Green qPCR Master Mix (Qiagen, Germany) according to the standard protocol. A list of primers sequences is provided in table (1).

Table (1): primer sequences for mice TGF- $\beta$, TNF- $\alpha$ and house-keeping GAPDH used for qPCR analysis of their mRNA expression in DSS induced UC in mice.

\begin{tabular}{|c|c|}
\hline Primer & Sequence \\
TGF- $\boldsymbol{\beta}$ (mouse) & $\begin{array}{r}\text { Forward:5-TGGAGCAACATGTGGAACTC-3 } \\
\text { Reverse:5- GTCAGCAGCCGGTTACCA }-3\end{array}$ \\
\hline TNF- $\boldsymbol{\alpha}$ (mouse) & $\begin{array}{r}\text { Forward:5- GCCTCTTCTCATTCCTGCTTG-3 } \\
\text { Reverse:5- CTGATGAGAGGGAGGCCATT -3 }\end{array}$ \\
\hline $\begin{array}{c}\text { GAPDH } \\
\text { (mouse) }\end{array}$ & Forward:5- GGGTTCCTATAAATACGGACTGC -Reverse:5- \\
\hline
\end{tabular}

\subsection{C- reactive protein estimation (CRP):}

Serum CRP was quantitatively measured by turbidimerty assay method by using BIOLABO Diagnostic analyzer.

\subsection{Complete blood count (CBC):}

CBC was determined by Mindray hematology analyzer.

\subsection{Histopathological examination:}

Specimens from colon of all animals were collected, fixed in neutral buffered formalin $10 \%$ and processed by paraffin embedding technique. Transverse sections of 4 - $5 \mu \mathrm{m}$ thick were prepared and stained with haematoxylin and eosin for light microscopic examination.

\subsection{Statistical Analysis:}

Data were expressed as the mean \pm SEM. Variables were compared using one way analysis of variance (ANOVA) followed by Turkey's post test. $\mathrm{p}<0.05$ was considered significant. All statistical analysis was conducted with GraphPad Prism (version 6, GraphPad Prism software, California, USA). 


\section{RESULTS:}

\subsection{Effects of UC induced by DSS on TGF- $\beta$ and TNF- $\alpha$ protein expression:}

We found marked elevation of TGF- $\beta$ and TNF- $\alpha$ proteins expression vs. $\beta$-actin protein in colon tissue of DSS treated mice in acute and chronic group compared to healthy control group (Figure $1 \mathrm{a} \& \mathrm{~b}$ ).



Figure (1): Effect of DSS on expression of TGF- $\beta$ \& TNF- $\alpha$ protein in mice colon tissues :( A) Expression of TGF- $\beta$ protein in colon tissue in different groups was normalized to $\beta$-actin protein. (B) Expression of TNF- $\alpha$ protein in colon tissue in different groups was normalized to $\beta$-actin protein. Data are expressed as mean $\pm \mathrm{SEM}$. $(\mathrm{n}=3 ; * \mathrm{p}<0.05 ; * * \mathrm{p}<0.01 ; * * * \mathrm{p}<0.001)$ compared to control group.

\subsection{Effects of UC induced by DSS on TGF- $\beta$ and TNF- $\alpha$ mRNA expression:}

Our results revealed significant increase in mRNA expression of both TGF- $\beta$ and TNF- $\alpha$ in both diseased groups vs. normal control group (Figure2 a \& b).
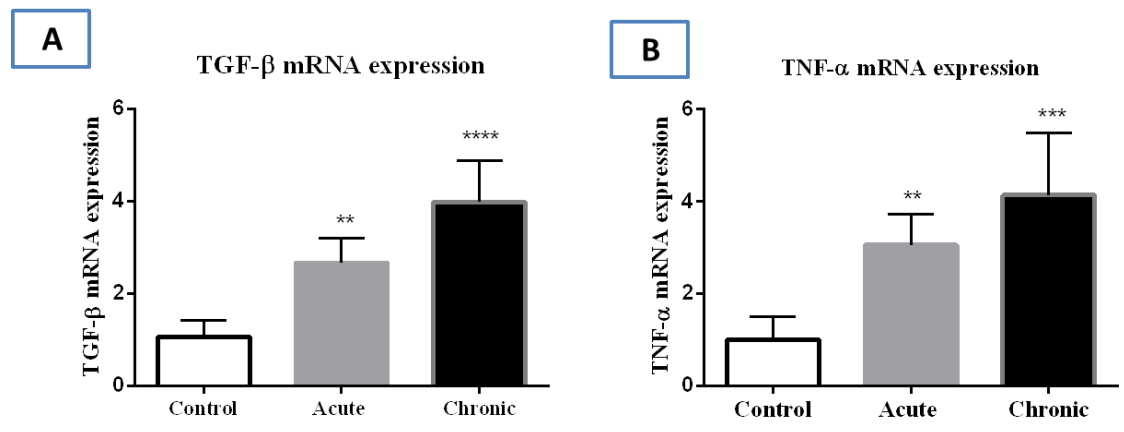

Figure (2): Effect of DSS on mRNA expression of TGF- $\beta$ \& TNF- $\alpha$ in mice colon tissues; (A) Expression of TGF- $\beta$ mRNA in colon tissue in different groups was normalized to mRNA of GAPDH. (B) Expression of TNF- $\alpha$ mRNA in colon tissue in 
different groups was normalized to mRNA of GAPDH. Data are expressed as mean \pm $\operatorname{SEM}(\mathrm{n}=5 ; * * \mathrm{p}<0.01 ; * * * \mathrm{p}<0.001 ; * * * * \mathrm{p}<0.0001)$ compared to control group.

\subsection{Effects of UC induced by DSS on CRP and ESR:}

In our study we found marked increase in traditionally inflammatory markers; CRP \& ESR in both acute and chronic UC groups compared to healthy control group. (Figure 3 a \& b).
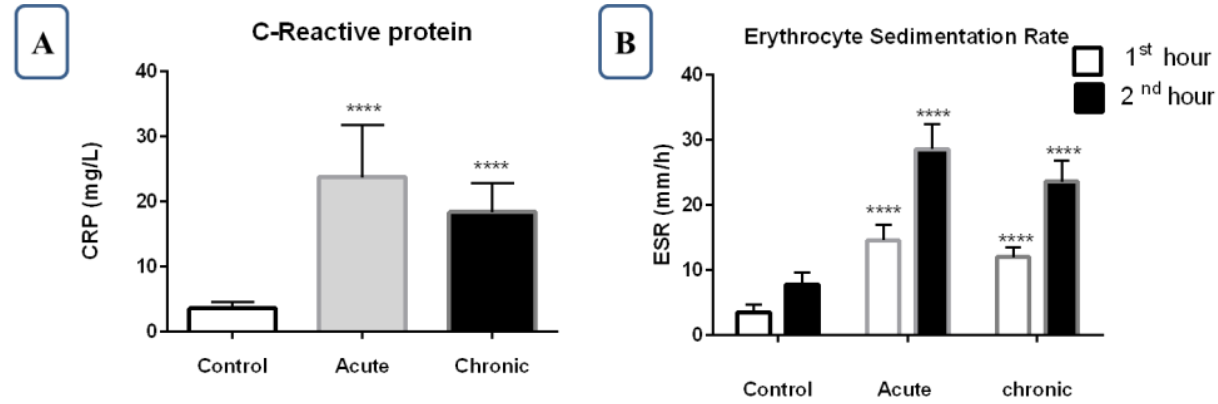

Figure (3): Effect of acute and chronic UC induced by DSS on elevated serum level of CRP (A) and ESR (B) compared with normal control group. Data are expressed as mean \pm SEM. $* * * * \mathrm{p}<0.0001,(\mathrm{n}=5)$.

\subsection{Effects of UC induced by DSS on Complete Blood Count:}

Results showed that hemoglobin was significantly decreased in parallel with significant decreases in red blood cells count in UC groups compared with normal control group (Figure 4 a \& b). Also, this study revealed marked leukocytosis with thrombocytosis in UC groups compared to healthy control group (Figure $4 \mathrm{c} \& \mathrm{~d}$ ).
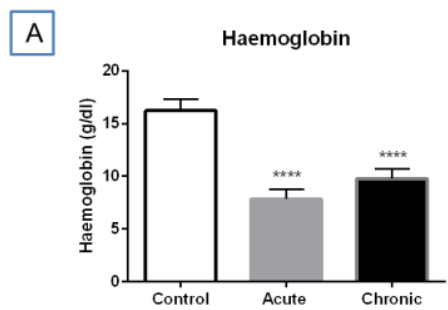

C

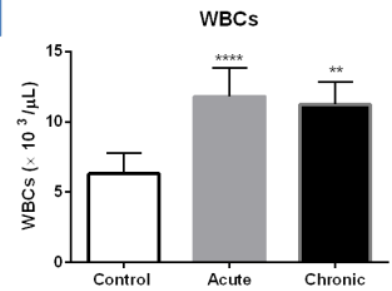

B
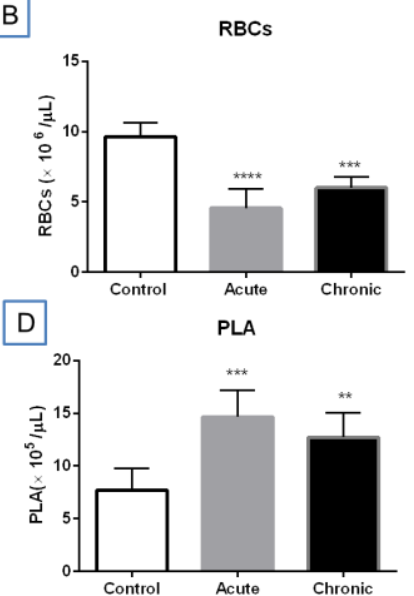

Figure (4): Effect of acute and chronic UC induced by DSS in decreased hemoglobin level (A), and RBCs (B) and elevation levels of WBCs (C) and platelet count (D) mean \pm SEM. $* * * * \mathrm{p}<0.0001 ; * * * \mathrm{p}<0.001 ; * * \mathrm{p}<0.01 ;(\mathrm{n}=5)$. 


\subsection{Effects of UC induced by DSS on Micro- and Macroscopical Changes in Colon} Tissues:

Histopathological examination of normal colon revealed architecture mucosa, crypts of Lieberkühn, submucosal \& muscularis layers (Figure 5 A). In contrary, histopathological investigation of colon of acute UC group showed epithelial loss, focal mucosal necrosis and submucosal edema associated with inflammatory cells infiltration (Figure $5 \mathrm{~B}$ ). Furthermore, remarkable microscopic lesions were recorded in colon of chronic UC group include marked necrosis and ulceration of the mucosa extending to the muscularis layer associated massive hemorrhage (Figure $5 \mathrm{C}$ ).

A

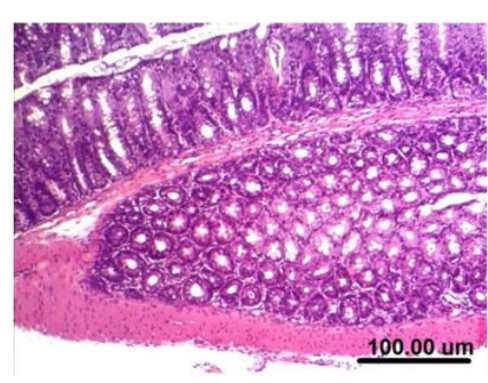

B

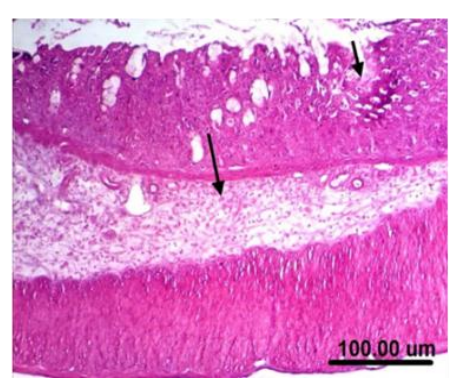



Figure (5): Microscopical investigation of colon revealed the following: A- Colon of normal control mice showing the normal histological architecture (mucosa, Crypts of Lieberkühn, submucosa and muscularis layers) (H \& E, scale bar 100um). B- Colon of mice treated with DSS (3\%) for 7 days showing focal mucosal necrosis (short arrow), submucosal edema associated with inflammatory cells infiltration (long arrow) (H \& E, scale bar 100um). C- Colon of mice treated with DSS (1.5\%) for 2 weeks showing marked necrosis and ulceration of the mucosa extending to the muscularis layer (short arrow) associated with massive hemorrhage (long arrow)(H \& E, scale bar 100um).

At the end of experiment, photographs of colon and anus of mice were taken. These photographs revealed bloody stool, diarrhea, ulcers and mucosal inflammation in both acute and chronic groups in compared to animals of normal control group (figure 6 a,b and c)

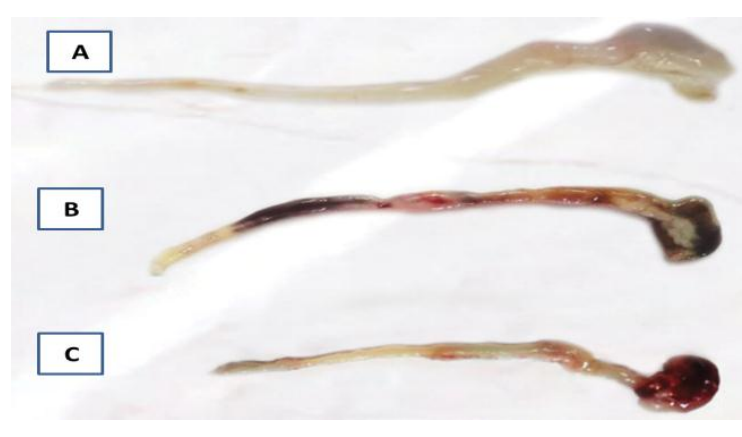

Figure (6): Macroscopical examination of DSS treated mice colon; A- Normal colon show no bloody stool or ulcers with normal mucosa. Colon of acute (B) and chronic (C) UC groups showed bloody stool, ulcers and mucosal inflammation. 


\section{Discussion:}

UC is a lifelong disease caused by genetic and environmental factors (Magro et al., 2017). The pathogenesis of UC includes deregulated immune responses to mucosal injury, with permanent inflammation and disruption of wound healing. The DSS model is the most widely used model for induction of UC due to its simplicity, reproducibility and rapidity. In our study, DSS treated mice groups developed sever colitis with typical signs involving: bloody diarrhea, reduced food intake with subsequent decrease in body weight as in UC human patients. A marked elevation occurred in TGF- $\beta$ protein and mRNA expression in acute and chronic UC groups vs. healthy control group. Previous studies demonstrated that, there is an elevation in TGF- $\beta$ production in ulcerative colitis (Perše and Cerar 2012, Marafini et al., 2013, Jovanovic et al., 2018). TGF- $\beta$ is plentiful in mammalian intestine. Many cell types contribute in production of TGF- $\beta$; e.g. epithelial cells, immune cells and fibroblasts (Babyatsky et al., 1996, Letterio and Roberts 1998). TGF- $\beta$ is the most important anti-inflammatory and regulatory cytokine in IBD (Sanchez-Muñoz et al., 2008). Previous studies revealed that, mice that have knockout of the TGF- $\beta 1$ gene develop IBD (Shull et al., 1992, Kulkarni et al., 1995). Furthermore, blocking TGF- $\beta$ RII in animal showed developing of colitis. TGF- $\beta$ regulates multiple immune responses of T-cells, B-cells, dantritic cells and macrophages (Ihara et al. 2017). TGF- $\beta$ elevation is reflected as compensatory mechanism to relive the symptoms of UC by promoting patient immunosuppressive effect ((Marek et al., 2002, Del Zotto et al., 2003). We found that elevation of TGF- $\beta$ was accompanied with significant increased level of TNF- $\alpha$, CRP and ESR in both acute and chronic UC groups compared to healthy control group. TNF- $\alpha$ is a pleiotropic cytokine, produced by macrophages in the colon with a wide range of biological activities including induction of inflammatory processes (Sartor 1994, Cianci et al., 2005). Our findings are harmonious with previous studies that exhibited highly upregulation of TNF- $\alpha$ in the mucosa of IBD patients (Stokkers and Camoglio 1995, Targan 2000, Sartor 2006, Geremia et al., 2014). On the other hand, the IBD inflammatory markers CRP \& ESR used in IBD patients diagnosis and follow were significantly elevated in UC groups vs. healthy control group. Lewis, 2011, exhibited that elevation of CRP \& ESR indicates presence of active UC. Furthermore, we found that the elevation of TGF- $\beta$, TNF- $\alpha$, CRP and ESR were associated with significant thrombocytosis, leukocytosis and higher platelet count. Those results documented in several past studies (TALBOT et al., 1986, Linskens et al., 2001, Payzin et al., 2006, Thapa et al., 2015). The mechanisms in charge of increase the platelet count in IBD still uncompleted understood however can be explained on the basis of a non-specific inflammatory reaction. Thrombocytosis is associated with thromboembolic events in patients with IBD, and may occur both in gastrointestinal tract and at extraintestinal sites (Dolapcioglu et al., 2014). Thromboembolic events represents the most cause of morbidity and mortality in patients with IBD (Dolapcioglu et al. 2014). The leukocytosis which showed by our study is consistent with previous studies that revealed increase in white blood cell count in IBD (Schoepfer et al., 2009, Iskandar and Ciorba 2012, Langhorst et al., 2016, Kassem et al., 2019). The significant decrease in RBCs and anemia that, we found are consistent with previous studies that revealed presence of moderate and severe anemia in IBD patients and murine models of colitis (Stein et al., 2010, Carter et al., 2013, Murawska et al., 2016, SambaMondonga et al., 2019). Anemia in IBD patients is one of the most causes of 
hospitalization (Samba-Mondonga et al. 2019). Intestinal blood loss, dietary limitations, and iron malabsorption caused by mucosal inflammation are the most causes of anemia in IBD.

\section{Conclusion}

In conclusion, our study revealed marked elevation of TGF- $\beta$ protein and mRNA expression in colon tissues of UC groups in comparison to normal colon tissues of control group. TGF- $\beta$ elevation occurred side by side with the elevation of other diagnostic inflammatory markers of UC disease; TNF- $\alpha$, CRP and ESR. Thus, TGF- $\beta$ can be used as a biomarker for diagnosis of active UC.

\section{Recommendation}

More studies on large groups of patient and cell lines are necessary to decide the significance of TGF- $\beta$ as a diagnostic marker of acute and chronic ulcerative colitis.

\section{Financial Disclosure}

This research did not receive any specific grant from funding agencies in the public, commercial, or not-for-profit sectors.

\section{Declaration of Interest Section}

The authors report no declarations of interest.

\section{References}

Ananthakrishnan A. N. (2015): Environmental risk factors for inflammatory bowel diseases: a review:Digestive diseases and sciences, 60(2): 290-298.

Babyatsky M. W., Rossiter G. and Podolsky D. K. (1996): Expression of transforming growth factors alpha and beta in colonic mucosa in inflammatory bowel disease:Gastroenterology, 110(4): 975-984.

Burri E., Manz M., Schroeder P., Froehlich F., Rossi L., Beglinger C. and Lehmann F. S. (2014): Diagnostic yield of endoscopy in patients with abdominal complaints: incremental value of faecal calprotectin on guidelines of appropriateness:BMC gastroenterology, 14(1): 57.

Carter P. R., Watts M. N., Kosloski-Davidson M., Prasai K., Grisham M. B. and Harris N. R. (2013): Iron status, anemia, and plasma erythropoietin levels in acute and chronic mouse models of colitis:Inflammatory bowel diseases, 19(6): 1260-1265.

Chan H. C.-h., Kim D. H., Lung P. F. C., Cheon J. H. and Ng S. C. (2015). Complications of inflammatory bowel disease. Atlas of Inflammatory Bowel Diseases, Springer: 175-186. 
Cianci R., Cammarota G., Raducci F. and Pandolfi F. (2005): The impact of biological agents interfering with receptor/ligand binding in the immune system:European review for medical and pharmacological sciences, 9(6): 305.

Del Zotto B., Mumolo G., Pronio A., Montesani C., Tersigni R. and Boirivant M. (2003): TGF- $\beta 1$ production in inflammatory bowel disease: differing production patterns in Crohn's disease and ulcerative colitis:Clinical \& Experimental Immunology, 134(1): 120-126.

Dolapcioglu C., Soylu A., Kendir T., Ince A. T., Dolapcioglu H., Purisa S., Bolukbas C., Sokmen H. M., Dalay R. and Ovunc O. (2014): Coagulation parameters in inflammatory bowel disease:International journal of clinical and experimental medicine, 7(5): 1442.

Esmat S., El Nady M., Elfekki M., Elsherif Y. and Naga M. (2014): Epidemiological and clinical characteristics of inflammatory bowel diseases in Cairo, Egypt:World journal of gastroenterology: WJG, 20(3): 814.

Fengming Y. and Jianbing W. (2014): Biomarkers of inflammatory bowel disease:Disease markers, 2014.

Geremia A., Biancheri P., Allan P., Corazza G. R. and Di Sabatino A. (2014): Innate and adaptive immunity in inflammatory bowel disease:Autoimmunity reviews, 13(1): 3-10.

Gray W. N., Denson L. A., Baldassano R. N. and Hommel K. A. (2010): Disease activity, behavioral dysfunction, and health-related quality of life in adolescents with inflammatory bowel disease:Inflammatory bowel diseases, 17(7): 15811586.

Ihara S., Hirata Y. and Koike K. (2017): TGF- $\beta$ in inflammatory bowel disease: a key regulator of immune cells, epithelium, and the intestinal microbiota:Journal of gastroenterology, 52(7): 777-787.

Iskandar H. N. and Ciorba M. A. (2012): Biomarkers in inflammatory bowel disease: current practices and recent advances:Translational Research, 159(4): 313-325.

Jenkins G. (2008): The role of proteases in transforming growth factor- $\beta$ activation:The international journal of biochemistry \& cell biology, 40(6-7): 1068-1078.

Johnston C. J., Smyth D. J., Dresser D. W. and Maizels R. M. (2016): TGF- $\beta$ in tolerance, development and regulation of immunity:Cellular immunology, 299: $14-22$.

Jovanovic M., Zdravkovic N., Jovanovic I., Radosavljevic G., Gajovic N., Zdravkovic N., Maric V. and Arsenijevic N. (2018): TGF- $\beta$ as a marker of 
ulcerative colitis and disease severity:Serbian Journal of Experimental and Clinical Research, 19(3): 229-236.

Kashiwagi I., Morita R., Schichita T., Komai K., Saeki K., Matsumoto M., Takeda K., Nomura M., Hayashi A. and Kanai T. (2015): Smad2 and Smad3 inversely regulate TGF- $\beta$ autoinduction in Clostridium butyricum-activated dendritic cells:Immunity, 43(1): 65-79.

Kassem A., Shabana H. A. and Aboelenin M. M. (2019): Comparative study the levels of plasma transforming growth factor- $\beta 1$, serum crp, fecal lactoferrin, and fecal calprotectin as biomarkers for disease activity in Egyptian patients with ulcerative colitis:The Scientific Journal of Al-Azhar Medical Faculty, Girls, 3(1): 79 .

Kulkarni A. B., Ward J. M., Yaswen L., Mackall C. L., Bauer S. R., Huh C.-G., Gress R. E. and Karlsson S. (1995): Transforming growth factor-beta 1 null mice. An animal model for inflammatory disorders:The American journal of pathology, 146(1): 264.

Langhorst J., Boone J., Lauche R., Rueffer A. and Dobos G. (2016): Faecal lactoferrin, calprotectin, PMN-elastase, CRP, and white blood cell count as indicators for mucosal healing and clinical course of disease in patients with mild to moderate ulcerative colitis: post hoc analysis of a prospective clinical trial:Journal of Crohn's and Colitis, 10(7): 786-794.

Letterio J. J. and Roberts A. B. (1998): Regulation of immune responses by TGF$\beta:$ Annual review of immunology, 16(1): 137-161.

Linskens R., Van Bodegraven A., Schoorl M., Tuynman H. and Bartels P. (2001): Predictive value of inflammatory and coagulation parameters in the course of severe ulcerative colitis:Digestive diseases and sciences, 46(3): 644-648.

Magro F., Gionchetti P., Eliakim R., Ardizzone S., Armuzzi A., Barreiro-de Acosta M., Burisch J., Gecse K. B., Hart A. L. and Hindryckx P. (2017): Third European evidence-based consensus on diagnosis and management of ulcerative colitis. Part 1: definitions, diagnosis, extra-intestinal manifestations, pregnancy, cancer surveillance, surgery, and ileo-anal pouch disorders:Journal of Crohn's and Colitis, 11(6): 649-670.

Manser C. N., Borovicka J., Seibold F., Vavricka S. R., Lakatos P. L., Fried M., Rogler G. and Study i. o. t. S. I. B. D. C. (2016): Risk factors for complications in patients with ulcerative colitis:United European gastroenterology journal, 4(2): 281-287.

Marafini I., Zorzi F., Codazza S., Pallone F. and Monteleone G. (2013): TGF-beta signaling manipulation as potential therapy for IBD:Current drug targets, 14(12): 1400-1404. 
Marek A., Brodzicki J., Liberek A. and Korzon M. (2002): TGF-beta (transforming growth factor-beta) in chronic inflammatory conditions-a new diagnostic and prognostic marker:Med Sci Monit, 8(7): 145-151.

Monteleone G., Kumberova A., Croft N. M., McKenzie C., Steer H. W. and MacDonald T. T. (2001): Blocking Smad7 restores TGF- $\beta 1$ signaling in chronic inflammatory bowel disease:The Journal of clinical investigation, 108(4): 601-609.

Murawska N., Fabisiak A. and Fichna J. (2016): Anemia of chronic disease and iron deficiency anemia in inflammatory bowel diseases: pathophysiology, diagnosis, and treatment:Inflammatory bowel diseases, 22(5): 1198-1208.

Ng S. C., Shi H. Y., Hamidi N., Underwood F. E., Tang W., Benchimol E. I., Panaccione R., Ghosh S., Wu J. C. and Chan F. K. (2017): Worldwide incidence and prevalence of inflammatory bowel disease in the 21st century: a systematic review of population-based studies:The Lancet, 390(10114): 27692778 .

Norouzinia M., Chaleshi V., Alizadeh A. H. M. and Zali M. R. (2017): Biomarkers in inflammatory bowel diseases: insight into diagnosis, prognosis and treatment:Gastroenterology and Hepatology from bed to bench, 10(3): 155.

Payzin B., Adakan F., Yalçin H., Cetinkaya G., Berkmen S., Eraslan S. and Unsal B. (2006): Natural coagulation inhibitory proteins and activated protein $C$ resistance in Turkish patients with inflammatory bowel disease:The Turkish journal of gastroenterology: the official journal of Turkish Society of Gastroenterology, 17(3): 183-190.

Perše M. and Cerar A. (2012): Dextran sodium sulphate colitis mouse model: traps and tricks:BioMed Research International, 2012.

Samba-Mondonga M., Constante M., Fragoso G., Calvé A. and Santos M. M. (2019): Curcumin induces mild anemia in a DSS-induced colitis mouse model maintained on an iron-sufficient diet:PloS one, 14(4): e0208677.

Sanchez-Muñoz F., Dominguez-Lopez A. and Yamamoto-Furusho J. K. (2008): Role of cytokines in inflammatory bowel disease:World journal of gastroenterology: WJG, 14(27): 4280.

Sartor R. B. (1994): Cytokines in intestinal inflammation: pathophysiological and clinical considerations:Gastroenterology, 106(2): 533-539.

Sartor R. B. (2006): Mechanisms of disease: pathogenesis of Crohn's disease and ulcerative colitis:Nature Reviews Gastroenterology \& Hepatology, 3(7): 390. 
Satsangi J., Silverberg M., Vermeire S. and Colombel J. (2006): The Montreal classification of inflammatory bowel disease: controversies, consensus, and implications:Gut, 55(6): 749-753.

Schoepfer A. M., Beglinger C., Straumann A., Trummler M., Renzulli P. and Seibold F. (2009): Ulcerative colitis: correlation of the Rachmilewitz endoscopic activity index with fecal calprotectin, clinical activity, C-reactive protein, and blood leukocytes:Inflammatory bowel diseases, 15(12): 1851-1858.

Shull M. M., Ormsby I., Kier A. B., Pawlowski S., Diebold R. J., Yin M., Allen R., Sidman C., Proetzel G. and Calvin D. (1992): Targeted disruption of the mouse transforming growth factor- $\beta 1$ gene results in multifocal inflammatory disease:Nature, 359(6397): 693.

Stein J., Hartmann F. and Dignass A. U. (2010): Diagnosis and management of iron deficiency anemia in patients with IBD:Nature Reviews Gastroenterology \& Hepatology, 7(11): 599.

Stokkers P. and Camoglio L. (1995): Tumor necrosis factor (TNF) in inflammatory bowel disease: gene polymorphisms, animal models, and potential for anti-TNF therapy:Journal of inflammation, 47(1-2): 97-103.

TALBOT R. W., HEPPELL J., DOZOIS R. R. and BEART Jr R. W. (1986). Vascular complications of inflammatory bowel disease. Mayo Clinic Proceedings, Elsevier.

Targan S. R. (2000): Biology of Inflammation in Crohn's Disease: Mechanisms of Action of Anti-TNF- $\alpha$ Alpha Therapy:Canadian Journal of Gastroenterology and Hepatology, 14(Suppl C): 13C-16C.

Thapa S. D., Hadid H., Imam W., Hassan A., Usman M., Jafri S.-M. and Schairer J. (2015): Persistent reactive thrombocytosis may increase the risk of coronary artery disease among inflammatory bowel disease patients:Digestive diseases and sciences, 60(10): 3062-3068.

Wu X.-W., Ji H.-Z., Yang M.-F., Wu L. and Wang F.-Y. (2015): Helicobacter pylori infection and inflammatory bowel disease in Asians: a meta-analysis:World journal of gastroenterology: WJG, 21(15): 4750.

Ye Y., Pang Z., Chen W., Ju S. and Zhou C. (2015): The epidemiology and risk factors of inflammatory bowel disease:International journal of clinical and experimental medicine, 8(12): 22529. 


$$
\begin{aligned}
& \text { التهاب القولون التقرحي التجريبي: عامل النمو التحولي بيتا كعلامة تشخيصية } \\
& \text { *عمر علي محمد'، حسني علي حسن '، هشام حماده طه' ، عبير شرف الدين عبدالرحبمَّ، كوكب عبدالعزيز }
\end{aligned}
$$

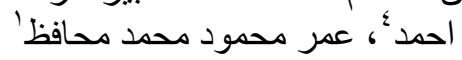

$$
\begin{aligned}
& \text { 'قسم الكيمياء الحيوية_ كلية الصيدلة - جامعة الأزهر فرع أسيوط - أسيوط - جمهورية مصر العربية } \\
& \text { 'قتم الكيمياء الحيوية ـ كلية الطب - جامعة أسيوط ـ أسيوط - جمهورية مصر العربية } \\
& \text { "آقسم طب المناطق الحارة و الجهاز الهضمي ـ كلية الطب - جامعة أسيوط ـ أسيوط - جمهورية مصر العربية } \\
& \text { "قسم الباتولوجي - كلية الطب البيطري - جامعة القاهرة ـ القاهرة - جمهورية مصر العربية } \\
& \text { omarfarghaly@azhar.edu.eg : البريد الالكتروني للباحث الرئيسي* }
\end{aligned}
$$

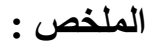

أوضحت در اسات سابقه أن عامل النمو التحولي بيتا يوجد بوفرة في أمعاء الثدييات حيث ينظم الكثير من الوظائف

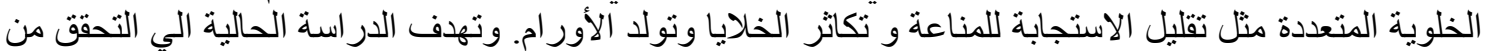

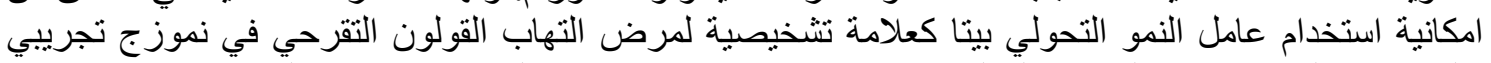

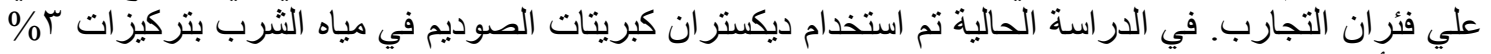

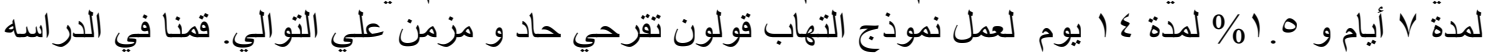

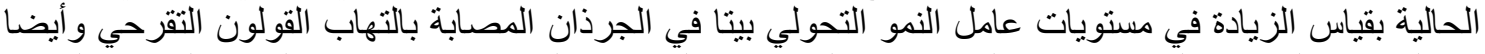

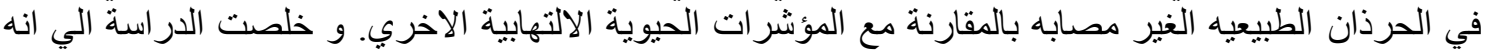



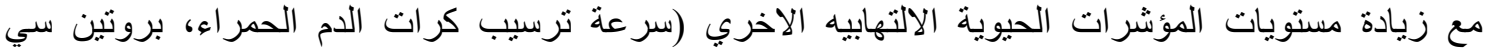
الحساس، عامل نخر الورم الفا ، كرات ات الدم البيضاء و الصفائح الأن الدموية).

التوصية: من الضروري إجر اء مزيد من الدراسات حول مجمو عات كبيرة من المرضي و خلايا القولون المزرو عة المّات

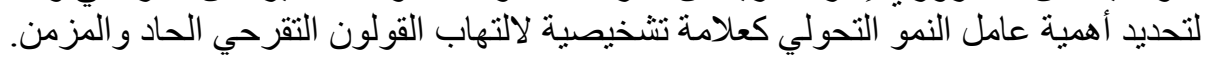



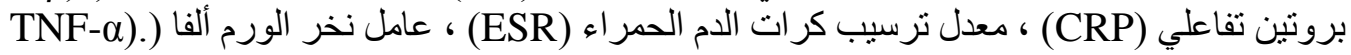

